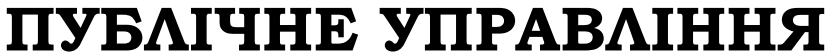

DOI https://doi.org/10.32782/2305-9389/2020.23.19

УДК 37.014.55:94(477)"1991/...

Безена Іван,

кандидат філософських наук, дочент, завідувач кафедри соиіально-гуманітарної освіти КЗВО «Дніпровська академія неперервної освіти» Дніпропетровської обласної ради, докторант Дніпропетровського регіонального інституту державного управління Національної академії державного управління при Президентові України

\section{РОЗВИТОК РЕГІОНАЛЬНОГО ДЕРЖАВНОГО УПРАВЛІННЯ В КОНТЕКСТАХ ЄВРОПЕЙСЬКОЇ ІНТЕГРАЦЇ̈: АСПЕКТИ ІСТОРІЇ СТАНОВЛЕННЯ ТА СТРАТЕГІї РОЗБУДОВИ (1991-2021 РР.)}

\begin{abstract}
У дослідженні проаналізовано історичні аспекти євроінтеграційних процесів у регіональній практиці і результати трансформацій структури, змісту діяльності обласних та місиевих органів влади, яка спрямована на сталий сочіально-економічний розвиток території $і$ задоволення запитів людини. Ключовими питаннями історичного розвитку державної регіональної політики є подолання наслідків авторитарних методів управління й вибудовування демократичних основ і механізмів ефективної співпраці регіональних органів державної влади та місиевого самоврядування, громадськими інституціями території, жителями сіл й міст.

Актуалізуються історичні аспекти формування адміністративно-територіального устрою, які націлені на ресурсне забезпечення діяльності сочіально-культурних об’єктів території та стратегї їх розвитку i трансформації. Окреслені процеси проходять у контексті вибудовування державного управління відповідно до ідеології європейського співтовариства. Демократизачія й децентралізачія спрямовані на перерозподіл владних повноважень «від иентру до регіону», розвиток демократичних основ на територіях, формування відповідального регіонального управління, повернення довіри громадян до влади і долучення людини до процесів врядування в громаді. Структурно-функиіональну модель системи держсавного управління на регіональному рівні було нормативно встановлено Конституиією Украӥни, яка прийнята 28.06.1996 року та залишається чинною донині.

У дослідженні розглянуто історичні процеси вибудовування органів державної влади регіону та місиевого самоврядування, прочесів формування ефективної співпрачі між владою і громадським активом території. Стратегія вибудовування партнерських стосунків спрямована на розбудову успішної території та ефективного розв'язання критичних проблем соиіально-економічного розвитку регіону. Сучасні регіональні практики підтверджують актуальність вибудовування нових стратегій розвитку території, наявності активних, професійних і системоутворюючих суб 'єктів публічної організаційної діяльності. Демократизація регіональної влади окреслена через публічне обговорення ситуації в громаді й експертизу суспільних проблем, відкриті процедури розгляду і прийняття публічних рішень, внутрішнього і зовнішнього бюджетування інфраструктури регіону.

Ключові слова: історія регіонального розвитку, Конституція Украӥни, стратегія розвитку регіону, сталий розвиток громади, взаємодія, євроінтеграція.
\end{abstract}

Bezena Ivan. Development of regional public administration in the contexts of European integration: aspects of the history of establishment and strategy of developments (1991-2021)

The study analyzes the historical aspects of European integration processes in regional practice and the results of transformations of the structure, content of regional and local authorities, which is aimed at sustainable socioeconomic development of the territory and meeting human needs. Key issues of historical development of state regional policy, overcoming the consequences of authoritarian methods of governance and building democratic foundations and mechanisms for effective cooperation of regional bodies of state power and local self-government, public institutions, residents of villages and towns.

The historical aspects of the administrative-territorial system formation are actualized, which are aimed at providing resources for the activities of socio-cultural objects of the territory and strategies for their development and transformation. The outlined processes take place in the context of building public administration in accordance with the ideology of the European community. Democratization and decentralization are aimed at redistributing power "from the center to the region", developing democratic foundations in the territories, forming responsible regional governance, restoring public confidence in government and involving people in community governance. The structural and functional model 
of the public administration system at the regional level was normatively established by the Constitution of Ukraine, which was adopted on June 28, 1996 and remains in force today.

The study examines the historical processes of building public authorities in the region and local government, the processes of forming effective cooperation between government and public assets of the territory. A strategy of building partnerships is targeted at building a successful territory and effectively solving critical problems of socioeconomic development of the region. Modern regional practices confirm the urgency of building new strategies for the development of the territory, the presence of active, professional and system-forming subjects of public organizational activity. Democratization of regional government is outlined through public discussion of the situation in the community and examination of social problems, open procedures for consideration and adoption of public decisions, internal and external budgeting of the region's infrastructure.

Key words: history of regional development, Constitution of Ukraine, regional development strategy, sustainable community development, interaction, European integration.

Постановка проблеми. Наша держава найближчим часом буде відзначати 30-і роковини незалежності, тому, на нашу думку, прагнення провести історичний аналіз процесів становлення, розвитку та стратегії розбудови державного управління на різних рівнях адміністрування $є$ актуальним. Тим більше, що Україна окреслила стратегічне прагнення до європейської інтеграції та уніфікації до стандартів ЄС: нормативно-правове законодавство; державне управління і публічні інститути (центру і регіонів); активізація діяльності громадянських інституцій. Адже до відповідальності державного управління належать питання забезпечення соціально значимої єдності діяльності центральних і регіональних органів влади, регулювання перспектив роботи суб'єктів соціально-економічної сфери регіонів.

Нині перед дослідниками проблем історії державного управління та адміністрування, державними і суспільними інституціями постають питання узагальнення процесів і тенденцій державотворення в Україні: активний порівняльний аналіз вибудовування моделі публічних органів влади регіонального рівня; критичне осмислення змісту ефективності інновацій у державному управлінні; результати структурних реформ, спрямованих на поглиблення інтеграції до європейських стандартів та стратегічних орієнтирів; становлення демократичних основ діяльності державного управління від центру до регіонів.

Аналіз останніх досліджень і публікацій. Дослідження проблем розвитку моделі державного управління та адміністрування в контекстах європейської інтеграції, пріоритету регіонального розвитку знаходить своє дослідження в науковому середовищі, а саме в роботах Г. Одінцова, В. Дзюндзюк, Н. Мельтюхова, Н.Миронова, В. Нікітін, Л. Усаченко, В. Тимцуник, Ю. Сурмін ін., які досліджують окремі етапи і процеси історії науково-практичної публічної діяльності на регіональному рівні за час незалежності України.

Мета статті. У дослідженні буде узагальнено історичні аспекти становлення та розвитку нових моделей державного управління на регіональному рівні з огляду на перспективи національної стратегії європейської інтеграції.

Виклад основного матеріалу. Національні дослідники зазначають, що доцільно виокремлювати такі етапи історії становлення системи державного управління в Україні: периий (грудень 1991 р. жовтень 1994 р.) - формування та розбудова нових інституцій державної влади України, основ внутрішньої та зовнішньої політики; другий (жовтень 1994 р. - листопад 1999 р.) - завершення становлення жорсткої централізованої вертикалі поділу гілок влади, реалізація конституційних основ державного управління за ознакою централізації повноважень та заниження ролі місцевого самоврядування; третій (листопад 1999 р. - грудень 2004 р.) - удосконалення системи державної влади, формування інститутів громадянського суспільства, політичне протистояння відносно перспектив розвитку держави; четвертий (січень 2005 р. - вересень 2010 р.) - трансформація державного управління та місцевого самоуправління, перехід від президентсько-парламентського до парламентсько-президентського типу республіканського устрою, конституційна криза в зв'язку із зміною типу правління; $n$ 'ятий (вересень 2010 - лютий 2014 р.) - скасування конституційної реформи, повернення до президентсько-парламентського типу організації влади, загострення кризи державного управління, розуміння потреби у проведенні реформи державного управління та організації дієвого місцевого врядування; шостий (березень 2014 р. по теперішній час) - визначення нових пріоритетів на поглиблення євроінтеграції через початок процесів демократизації, децентралізації влади, перерозподілу владних повноважень від центру до регіону, перегляд адміністративного поділу в регіонах, реформу служби в державному управлінні та місцевому самоврядуванні, пошук шляхів повернення суспільної довіри до діяльності влади [1, с. 25].

В окреслених історичних контекстах євроінтеграція України й надалі залишається поки що тільки перспективою, яка безпосередньо залежать від втілення в життя реальної демократії та інших загальновизнаних у співтоваристві цінностей, які відображені в Копенгагенських критеріях - критеріях членства 
в СС [2]. Відповідно, національна державна політика визначається стратегічно як перспектива, яка базується на цих критеріях, має всебічно враховувати євроінтеграційні концепти: підвищення прозорості, відкритості та публічності в діяльності органів державної влади; шляхи комунікації із громадянами; політична стабільність установ, які гарантують демократію, верховенство права, дотримання прав людини та захист прав етнічних меншин; дієва система ринкової економіки; членські зобов'язання, що випливають із факту вступу до $\mathrm{CC}$, зокрема визнання його політичних, економічних та монетарних цілей.

1991 р. визначив водорозділ між «до і після», тобто «до» від періоду входження України до територій, які включено до складу СРСР, «після» - часи становлення і розвитку державотворчих процесів незалежної держави. Відповідно, незалежна Україна у спадок від авторитарної державної системи отримала стару модель державного управління, адміністративно-територіального поділу та принципами й змістом структурно-організаційного управління територіями держави.

До 1991 р. помічаємо традиційну радянську модель державного управління, яка будувалася командноадміністративною системою партійного керівного впливу на зміст роботи органів публічної влади на центральному та регіональному рівні. Філософією державного управління та реальністю організаційної практики життєдіяльності було питання «керівної і спрямовуючої сили суспільства» - Комуністичної партії, яка визначалася Конституцією Української РСР (в редакції 1978 р.) [3]. Саме партія визначала перспективи соціально-економічного розвитку територій, вирішення ключових кадрових питань та подолання кризових питань регіонів. Водночас в окреслений період регіональну владу представляли місцеві (обласні, міські та районні) ради народних депутатів та їх виконавчі комітети як формальні інститути управління. Жорстка централізація радянської економіки, монополізація командно-адміністративної системи державного управління та відсутність гнучкості системи підтверджують неспроможність влади забезпечити сталий розвиток території. Відповідно, процедури і процеси викривлення в діяльності органів державного та партійного управління привели до загострення регіональної кризи і краху командно-адміністративної радянської системи.

Необхідно зазначити, що у 1991 р. до складу України входили 27 адміністративно-територіальних одиниць: 25 областей (регіонів) та 2 міста загальнодержавного підпорядкування (Київ та Севастополь). Регіони було поділено на 490 райони, які своєю чергою мали поділ на сільські, селищні та міські територіальні одиниці. У країні та регіонах безпосередньо загострювались політичні та соціальноекономічні проблеми, які приводили до втрати керованості ситуації і протистояння політичних еліт на загальнодержавному та регіональних рівнях.

Саме 31991 р. почалися аналітично-пошукові процеси в розробленні стратегічних перспектив, вибудовування нової моделі державного управління від центру до регіонів та формули адміністративнотериторіального поділу держави. Вже у лютому 1991 р. пройшла перша структурна зміна однієї з областей Української РСР - Кримської області, яка отримала адміністративний статус - Республіка Крим в складі Української РСР (пізніше - Автономна Республіка Крим (далі - АРК)). Інші суб'єкти регіонального публічного рівня залишались у старому адміністративно-територіальному устрої і організації структури органів влади, який було сформовано ще за часи Радянської України.

01.12.1991 р. пройшли перші в незалежній державі вибори Президента України, за результатами загальнодержавних виборів перемогу отримав Л. Кравчук. 3 огляду на те, що виникали проблеми із вибудовуванням нової моделі державного управління від центру до регіону, представники центральної влади підготували нову законодавчу базу. Вона визначала перспективи формування міцної президентської владної вертикалі від центра до обласного й районного рівня, яка за їх стратегією буде орієнтована на жорстку (майже радянську) централізацію державного управління. Унаслідок окреслених перспектив 05.03.1992 р. Верховна Рада України затвердила Закон України «Про Представника Президента України» (був чинним до 12.06 .1997 р.). Надалі відповідним Указом Президента України від 14.04.1992 p. № 252 «Про затвердження Положення про місцеву державну адміністрацію» було здійснено формування нормативно-правових актів, які врегульовували організаційне оформлення місцевих державних адміністрацій на обласному та районному рівні [4; 5]. А для їх створення і виокремлення було визначено із складу відповідних виконавчих підрозділів місцеві ради. Основним ризиком державного управління окресленого процесу була слабкість кадрового резерву.

Зіставлення засвідчує, що фактично було здійснено законодавче закріплення за президентською владною вертикаллю повноважень, які обмежували вплив місцевої ради на регіональну соціально-економічну ситуацію. Представники Президента України ставали на чолі місцевих державних адміністрацій та наділялися повноваженнями публічного управління на відповідних адміністративних територіях. Вказаним Указом Президента України визначалося, що «місцева державна адміністрація є правонаступником виконавчих комітетів відповідних Рад народних депутатів щодо прийнятих ними рішень, 
взятих зобов'язань та покладених законодавством обов'язків у тій частині, яка не суперечить Закону України «Про Представника Президента України» та Закону України «Про місцеві Ради народних депутатів та місцеве і регіональне самоврядування» [4; 6]. Окреслені були правові норми розбудови структурно-функціонального державного управління, вже через певний проміжок часу президентська вертикаль влади черговий раз робила спробу переглянути розвиток структури адміністрування в державі, зберегти свій вплив на регіональні процеси, але досить не стійка політична ситуація та відсутність пропрезидентської більшості в парламенті та інтереси регіональних еліт не завжди були схильні до таких структурних процесів і компромісу.

Конституція України (1996) закріпила норму, що виконавчу владу в областях і районах здійснюють місцеві державні адміністрації, які підпорядковані Президенту України та Кабінету Міністрів України, органам центральної виконавчої влади, а в частині делегованих повноважень підзвітні місцевим радам відповідного рівня [7]. У реальних практиках були певні перекоси у взаємовідносинах регіональних органів державної влади та місцевого самоврядування, які були пов'язані з процедурами дублювання повноважень, неврегулюванням окремих норм та процесів тощо. Проводячи відповідні аналітичні паралелі в адміністративно-територіальної конфігурації держави і регіонів, в основу поклали принципи оптимізації територій та пошуки нової моделі побудови державної влади в регіоні. В окресленому питанні узагальнювався досвід вибудовування структури влади і адміністративного поділу в країнах Євросоюзу, особливо у колишніх соціалістичних країнах, які вже тепер є повноправними членами європейської спільноти. Адже в процесах переходу від комуністичної моделі побудови владних інституцій країн було розпочато процедури оптимізації мережі суб'єктів регіональної влади та адміністративнотериторіального поділу.

Прикладом слугує досвід Польщі, яка після грунтовних досліджень у період 1990-1999 рр. розпочала багаторівневі консультації і суспільне обговорення концепцій реформи 3 децентралізації та перейшла до практичної іiі реалізації. 3 01.01.1999 р. число воєводств було скорочено із 49 до 16, а також число повітів - до 380 (в їх числі 66 міських), а 2477 гмін стали базовим органом місцевого самоврядування [8]. У контекстах адміністративної реформи паралельно проходили процеси перерозподілу повноважень між центральною та місцевою владою у сфері відповідальності та формування самодостатності. Основою владної реформи було питання розвитку і розбудови місцевого самоврядування і вдосконалення ефективності їхньої діяльності для сталого розвитку громади й підвищення якості життя громадян. Автори публічної реформи керувалися принципами системності в поділі й побудові структури органів влади, їх функціональності, соціально-економічної самодостатності, цивілізованості і стратегіями економічних пріоритетів держави.

Одночасно в Україні теж почали проходити організаційно-управлінські процеси з підготовки національних проєктів децентралізації, перерозподілу владних повноважень, нової моделі адміністративнотериторіального поділу, обмеження втручання державної влади. Без сумніву, багатоваріантні проєкти, наради, консультування, політичні протистояння і підготовка відповідних нормативних актів, процедури затягнулися в часі та не привели до процесу практичної реалізації визначеної публічної реформи.

«Утрехтська декларація про добре місцеве та регіональне врядування в неспокійний час: проблеми змін» (17.11.2009 р.) визначає стратегії розвитку регіональної влади та іiї ефективності. В ії контекстах у практиках міжрегіональної співпраці визначаються активні процедури з розвитку партнерства й обміну досвідом між містами України та містами країн ЄС у різних галузях: містобудування, транспортної логістики, житлово-комунальної сфери, поводження з відходами, освіта, медицина, культура тощо. Всі окреслені партнерські заходи були зорієнтовані на євроінтеграційну політику регіонів України, яка була закріплена 26.09.2014 р. «Угодою про асоціацію між Україною та Свропейським Союзом $(Є C) »[9 ; 10]$. Конституція України (ст. 133) визначає, що «територіальний поділ України грунтується на засадах єдності та цілісності державної території, поєднання централізації і децентралізації у здійсненні державної влади, збалансованості соціально-економічного розвитку регіонів, з урахуванням їх історичних, економічних, екологічних, географічних і демографічних особливостей, етнічних і культурних традицій» [7]. Систему адміністративно-територіального устрою держави становлять АРК, області, райони, міста, райони в містах, селища та села, а базовим рівнем влади в регіоні визначено об'єднану територіальну громаду.

Тільки 01.04.2014 р. Кабінет Міністрів України схвалив Концепцію реформування місцевого самоврядування та територіальної влади в державі. Координацію діяльності органів влади із реалізації реформи 3 децентралізації здійснює Національної ради реформ, яка утворена Президентом України. Таким чином, було розпочато реформу, метою якої стали процедури поглиблення демократичних основ структурної і змістової організаційно-діяльнісної побудови державного управління. 
Стратегічно визначено, що місцева влада має відійти від старої моделі формально-діючого представницького органу державної влади, відродити нову систему відповідальної діяльності в самоврядній громаді та створити змістові передумови для розвитку громадсько активної й освіченої особистості [11]. Певна річ, що нарешті державна влада України вже знайшла політичну волю та перейшла до процесу впровадження комплексної реформи публічної влади і нової структури адміністративно-територіального поділу регіонів країни.

Потрібно зазначити, що у 2014 р. розпочався значний нормотворчий процес: Кабінет Міністрів України затвердив Концепцію реформи місцевого самоврядування та територіальної організації влади в Україні, Верховна Рада України прийняла закони України «Про співробітництво територіальних громад», «Про добровільне об'єднання територіальних громад» та внесла зміни до Бюджетного і Податкового кодексів - щодо фінансової децентралізації. Окреслені чинники відкрили процедури із створення на базовому рівні нових об'єднаних громад та створив передумови для їх самодостатності і відповідальності відповідно до Європейської хартії місцевого самоврядування [12; 13; 14]. Відповідно, Законом України від 16.04.2020 p. № 562-IX «Про внесення змін до деяких законів України щодо визначення територій та адміністративних центрів територіальних громад», постановами Кабінету Міністрів України визначено нові адміністративні центри та затверджено нові межі 1470 спроможних територіальних громад, в яких у жовтні 2020 року проведено місцеві вибори на новій територіальній основі [15].

Метою публічної реформи визначено такі чинники: по-перше, формування ефективного місцевого самоврядування та підвищення його спроможності й відповідальності за справи на території; nо-друге, територіальна організація влади для забезпечення повноцінного життєвого середовища для громадян; по-третє, розширення надання високоякісних та доступних публічних послуг для громадян; по-четверте, становлення інститутів прямого народовладдя та врядування на рівні малих одиниць; no-n'яте, визначення балансу між узгодженням інтересів держави та територіальних громад. Незаперечно, наслідками тривалої державної політики тотальної централізації влади в Україні стали негативні чинники: істотна залежність територій від рішень та бюджетування з центру; низький рівень інвестиційної привабливості територій; інфраструктура, фінанси та кадри підтримували слабкість громади і їі спроможність; деградація сільської місцевості та іiї середовища; негативні тенденції демографії та соціального благополуччя сім'ї; низька якість надання публічних послуг; низький рівень довіри до влади; високий рівень корупції; низька ефективність управлінських рішень [16, с. 640; 17, с. 145].

Не викликає жодних сумнівів, що об’єктивним фактором, який спричинив початок реформи, є й те, що на їі початку тільки 6 регіонів в Україні були повністю самодостатніми, що, відповідно, за результатами соціально-економічного розвитку викликало значну регіональну диспропорцію, а також негативно впливало на якість життя та послуг для українців. Окреслені регіональні виклики вимагали проведення корінних реформ у частині трансформації державного управління, розбудови повноцінного місцевого самоврядування та територіальної організації влади в Україні.

32015 року активно розпочались процеси утворення об'єднаних територіальних громад і розвиток міжрегіонального партнерства по горизонталі в межах нових територіальних одиниць. Нині завдяки запровадженню міжмуніципального співробітництва нові територіальні громади та райони отримали змогу консолідувати зусилля й реалізовувати спільні інфраструктурні проекти. Зокрема, за результатами окресленої роботи вже 1354 територіальних громад уклали 604 договори про співробітництво на міжрегіональному рівні. Як ми раніше зазначали, практична діяльність органів регіональної влади оголила проблеми в подоланні соціально-економічної диспропорції їх розвитку, місцевих процесах державного управління та взаємовідносинах із місцевим врядуванням, адже в країнах ЄС окреслено основні напрями регіональної політики для подолання дисбалансу та впровадження низки регіональних спеціальних програм у вирівнюванні соціально-економічного розвитку територій. Ключовим аспектом діяльності сучасного державного управління є вплив на всі сфери держави інформаційнокомунікативних технологій, суспільство втрачає характерні риси попередніх етапів розвитку (класи, маси, традиційності партій, інструменти представницької демократії) і виникає нова конфігурація мінісуспільство [18-22].

Як ми раніше зазначали, станом на 01.01.2015 р. в Дніпропетровській області був адміністративнотериторіальний поділ, фактично сформований ще на початку 60 -х років XX століття та включав: 22 сільських райони та 13 міст обласного підпорядкування, 288 сільських і селищних рад. Станом на 01.01.2021 р. за результатами реформи 3 децентралізації в регіоні створено 7 районів, до складу яких входять нові 86 громад (міських, селищних та сільських) і в складі яких утворено 122 старостинських округи [23]. Історія реформи державного управління триває, адже сформовано стратегічні перспективи, які зорієнтовано на демократизацію і децентралізацію влади в Україні. 
Висновки 3 дослідження і перспективи подальших розвідок у цьому напрямі. Таким чином, за результатами дослідження як теоретичної, так і практичної конфігурації історії державного управління на регіональному рівні в контексті євроінтеграції ми дійшли висновків: 1) з 1991 р. в Україні розпочався новий історичний етап формування регіональної державної політики в розвитку демократії, розбудови державного управління, органів влади і формування відповідального місцевого самоврядування; 2) окреслено загальні стратегії та пріоритетні механізми євроінтеграційних процесів на регіональному рівні за зразками $€ C$; 3) ключовою є політична воля, яка визначила початок у 2014 р. децентралізації влади на регіональний рівень; 4) розпочато становлення нової інноваційної моделі управління громадою, яка розвиває комфортне середовище людини; 5) визначено етапи розбудови служби в органах місцевого самоврядування, яке стає повноправним осередком сталого розвитку регіону. Історія змін у державному управління України триває, від них залежить, чи відбудеться українська національна мрія - заможна і демократична держава.

За результатами дослідження окреслено проблеми досліджень: історичні аспекти міжрегіональної співпраці й інноваційного розвитку регіональної системи.

\section{Література:}

1. Усаченко Л.М., Тимцуник В.І. Історія державного управління в Україні. Київ : ТОВ «НВП «Інтерсервіс», 2013. 292 с.

2. Копенгагенські критерії членства у Європейському Союзі. Сайт Міністерства закордонних справ України. URL: https://mfa.gov.ua/yevropejska-integraciya/vidnosini-ukrayina-yes/kopengagenski-kriteriyi-chlenstva-v-yevropejskomusoyuzi

3. Конституція Української РСР. Київ, 1978. URL: https://zakon.rada.gov.ua/laws/show/888-09\#Text

4. Про Представника Президента України : Закон України N 394/92 (394/92 ) від 24.07.1992 p. URL: https://zakon.rada.gov.ua/ laws/show/2167-12\#Text

5. Про Положення про місцеву державну адміністрацію : Указ Президента України від 14 квітня 1992 р. N 252. URL: https://zakon.rada.gov.ua/laws/show/252/92\#Text

6. Про місцеві Ради народних депутатів та місцеве і регіональне самоврядування : Закон Української РСР від 7 грудня 1990 p. N 533-XII. URL: https://zakon.rada.gov.ua/laws/show/533-12\#Text

7. Конституція України. Київ, 1996. 45 c. URL: https://zakon.rada.gov.ua/laws/show/254к/96-вр\#Text

8. Курілов Ю.Ю. Регіоналізація, децентралізація та адміністративна реформа в Європі: теоретико-методологічний аспект. Аспекти публічного управління. 2018. Том 6. № 11-12. С. 72-84.

9. Утрехтська декларація про добре місцеве та регіональне врядування в неспокійний час: проблеми змін. Ухвалена 17.11.2009 р. 16-ою сесією конференції Свропейських міністрів, відповідальних за місцеве і регіональне управління. URL: https://zakon.rada.gov.ua/laws/show/994_a16\#Text

10. Угода про асоціацію між Україною та Європейським Союзом (ЄС). Офіиійний вісник Украӥни. 2014. № 75, Т. 1, ст. 83.

11. Безена I.М. Сучасні механізми регулювання освітньої системи регіону: стратегії планування та реалізації. Вчені записки ТНУ імені В.І. Вернадського. Серія: Державне управління. 2020. Том 31 (70) № 5. С. 7-11.

12. Про схвалення Концепції реформування місцевого самоврядування та територіальної організації влади в Україні : Постанова КМУ від 1 квітня 2014 р. № 333-p. URL: https://zakon.rada.gov.ua/laws/show/333-2014-\%D1\%80\#Text

13. Про співробітництво територіальних громад : Закон України. Відомості Верховної Ради (BВР). 2014. № 34. Ст. 1167.

14. Про добровільне об’єднання територіальних громад : Закон України. Відомості Верховної Ради (ВВР). 2015. № 13. Ст. 91.

15. Реформа децентралізації. Урядовий портал. URL: https://www.kmu.gov.ua/diyalnist/reformi/efektivne-vryaduvannya/ reforma-decentralizaciyi

16. Akimova L., Khomiuk N., Bezena I., Lytvynchuk I., Petrove O.. Planning of Socio-Economic Development of the Territories (Experience of European Union). International Journal of Management (IJM). Volume 11, Issue 4, April 2020, pp. 638-646.

17. Kryshtanovych M., Petrovskyi P., Khomyshyn I., Bezena I., Serdechna I. Peculiarities of Implementing Governancein the System of Social Security. Business, Management and Education. 18 (1), s. 142-156. Litva. https://doi.org/10.3846/ bme. 2020.12177

18. Перспективний план формування територій громад Дніпропетровської області : Розпорядження Кабінету Міністрів України від 20.05.2020 p. № 601-p. URL: https://zakon.rada.gov.ua

19. Бжезінський 3. Стратегічне бачення: Америка і криза глобальної влади / Пер. $з$ англ. Лелів Г. Львів : Літопис, 2012. $168 \mathrm{c}$.

20. Сторонянська I.З., Беновська Л.Я. Фінансова спроможність регіонів у контексті бюджетно-податкової децентралізації. Фінанси України. 2015. № 6. С. 44-37.

21. Парламентські процедури. Посібник для депутатів місцевих рад та активістів громад. Волинський ресурсний центр. URL: http://ipo.org.ua/wp-content/uploads/2015/06/web2.pdf

22. ЄВРОПЕЙСЬКА ХАРТІЯ місцевого самоврядування, 15 жовтня 1985 року. URL: https://zakon.rada.gov.ua/laws/ show/994 036\#Text

23. Децентралізація дає можливості - Дніпропетровська область: формула успіху. Сайт Дніпропетровського ЦРМС. URL: https://decentralization.gov.ua/areas/0562 